\title{
Introduction: The Cabinet as a Principle of Government
}

The Prime Minister lives in and with and by the Cabinet. The Cabinet is a constitutional principle (or a principle of government) as well as an institution. It represents the Cabinet as Council, the Cabinet system (of committees and sub-committees and meetings) and the Cabinet as 'The Colleagues' (Cabinet ministers mainly). Cabinet also represents the constitutional principle of collectivity and the mode of working, collegiality. It is the working framework and moral code of British government, honoured often in the evasion, but acknowledged, even respected. (The strength of the British Constitution is measured by the respectful language used in its evasion.)

The Cabinet is not based on a constitution, or a set of rules, but on precedent and practice firmed into custom and convention; but the working rules of Cabinet government are set out in a confidential document handed to new ministers, Questions of Procedure for Ministers. This, Hennessy says, is 'the nearest thing we have to a written constitution for British Cabinet government' (1986, p. 7). 'Questions' has grown over the years from four pages in 1945 to twenty-seven in the mid-1970s. It deals with simple procedures for a Cabinet Minister, but also sets out rules on committees, collective responsibility and confidentiality. The latter is heavily emphasised. The Cabinet procedures of British government are not public procedures. Hennessy prints the 1952 version, much of which remains unchanged (Hennessy 1986, pp. 8-13). 